\title{
Cooperatives of Farmers in Oman
}

Adela P. Balasa, Ghadeer Saif Khamis Al-Mashaikhi, and Noorul Shaiful Fitri Abdul Rahman

\section{ABSTRACT}

This study focuses on explaining the concept of farmers' cooperatives which contribute to raising the Omani economy, achieving security and food balance, and contributing to the eradication of poverty, hunger and unemployment. The aim of this paper is to find areas of deficiency concerning the implementation of farmer cooperatives in Oman. The study follows the philosophy of realism, as it is delivering real and accurate information. The text uses a mixed method by combining qualitative and quantitative. The research uses questionnaire showing the responses of farmers and ordinary people to collect the data. In addition, an interview showing the importance and the factor of implementing farmer cooperatives. This study uses interviews and questionnaire to gather the data needed to fill the gaps. The findings of this research add deep discovery to the previous studies, regarding the unawareness and knowledge among farmers about the importance, causes and positive effects of cooperatives among farmers and the negative effects that may occur to farmers for refusing to enter farmers' cooperatives and the factors of implementing farmer's cooperatives. Additional research in this topic is needed for full understanding of making strong relationships and trust between farmers, which convince them to join farmers' cooperatives. The value of this study lies in raising the level of farmer's cooperatives in Oman because of its invaluable role in improving livelihoods, achieving sustainable development, increasing profitability and increasing productive efficiency by finding the common reasons that prevent farmers to join these cooperatives.

Keywords: Farmers, Agriculture Cooperatives, Farmers Cooperative, Agriculture Sector.

\section{INTRODUCTION}

Agriculture cooperative it all about an action of farmer collective for the processing and marketing of the farm's product, production and purchase of farm' inputs. It aims to increase the farmer's income and production by linking them with information, agricultural inputs, finance, and market's output. Cooperatives enable individuals to achieve their aims, which they cannot achieve them by themselves. For instance, cooperatives can help to reduce risks, improve service and product quality, and benefit from the economy of scale to reduce their costs of hiring services or acquiring inputs such as transport and storage. Also, they can involve the members in the decision-making process, which create employment opportunities and enable farmers to be more resilient to the unstable market. The issue has raised because farmers face limitations of resources to pool their productions. Within the agriculture sector, many situations appear in which it is too expensive for farmers to market their products or services. The farmers will, hopefully benefit from the research by looking at the value and importance of cooperatives. This study begins to address central issues that have been experienced by the farmers on remote villages in Oman. Main questions: How can cooperatives use a tool to develop the performance of the farmers in the agriculture sector?

\author{
Submitted : February 27, 2021 \\ Published : March 20, 2021 \\ ISSN: 2507-1076 \\ DOI: $10.24018 /$ ejbmr.2021.6.2.784
}

Adela P. Balasa*

International Maritime College, Oman.

(e-mail: adela@imco.edu.om)

Ghadeer Saif Khamis Al-Mashaikhi

International Maritime College, Oman.

(e-mail: ghadeer.saif@ outlook.com)

Noorul Shaiful Fitri Abdul Rahman

International Maritime College, Oman.

(e-mail: noorul@imco.edu.om)

*Corresponding Author
It is worthy to study farmer's cooperatives in Oman, to bring new ideas and philosophies to be implemented and willing to enhance the level of farmer's cooperatives. In the researcher's view, farmer's cooperatives can help the farmers to provide their sources and produce better performance and it help the country form the economic side.

\section{LITERATURE REVIEW}

The arguments from the different resources regarding cooperatives of farmer in Oman were covered in this section.

According to Chiputwa, et al. [1], farmers are pressurized or burdened with the high farms inputs prices, inadequate productions of infrastructure, inefficiency of farming techniques, heavy constraints to have credit facilities, and poor market. This is a very ugly consequence which further compounded with the government authorities' intention to remove all the subsidies on the farm input resources including agro-chemicals and chemical fertilizer and also due to the heavy downturn in the economic conditions. However, cooperative farming option has been coming into the existence as a vibrant way in order to efficiently mobilize framers to form the pool and group resources. This helps farmers to become more effective in the production of agricultural activities. 
As indicated by Feng et. al. [2] that cooperative farming allows farmers to have a sound production. It is the reason that cooperatives are used as a viable tool in order to enhance the farmer's performance in agricultural sector. It is further stated that due to the cooperatives farmers will have low prices for farm inputs, good market conditions, effective techniques for farming, high and adequate productions of infrastructure and low constraints to have credit facilities.

It is denoted by Hakelius \& Hansson [3] that cooperatives serve farmers in Oman a fundamental tool to achieve the security of food at the household level. It is further stated that cooperatives are considered as the unique and propelling institutional intervention to attain the high level of food security in the premises of any nation. In addition to this, Oman is more comprehensively focusing on the cooperatives in farming because many of the developed nations likes Canada, Australia, European nations, china and japan have gained the self-sufficiency of food by cooperatives.

In the statement of Chiputwa \& Qaim [4] cooperatives were explained under the profit model as a practical tool for collective action and collaboration which intention is to reinforce and build communities, and also allows provision of the favourable climate for investment. Moreover, it caters the capability of the reduction of spatial inequality. It is even responsible for the promotion of equitable sharing regarding the benefits and cost development. It tends to promote mongrelized empowerment, economic democracy, preconditions for shared responsibility and sustainable development in Oman.

\section{A. The Reasons for the Establishment of Cooperatives among Farmers in Oman}

It is depicted by Hao et. al. [5] that spatial variation was examined in the agricultural development. This is a very poor indicator of the worse agricultural development. Therefore, restructuring in the line of the agricultural and its prospective development is highly needed for having the effective and efficient agricultural growth. It was the reason that establishment of cooperatives among farmer in Oman is essentially required in order to bring advancement in the agricultural system.

It is highlighted by Liang et. al [6] that the Oman was facing the issue of high farms inputs prices and heavy constraints to have credit facilities. It was the reason that the cooperatives functioning was introduced in the agricultural market. It helps in lowering down the prices for farms input and also becomes the removal to the constraint for approaching credit facilities. Agricultural cooperatives their members socially and economically by evolving them in a vibrant decision-making process that caters the added ruler opportunities for employment and allow them to become highly resilient to the environmental and economic shocks. It is wonderful initiative which allows agricultural associated to bring vibrant solution in farming so the increased and better output may achieve [7].

Inefficiency of farming techniques and poor market was another reason to bring cooperatives farming in Oman Van Rijsbergen et. al. [8]. This is highly beneficial for Omani Farmers to compile their agricultural activities more constructively and comprehensively. It is further stated that Agricultural cooperatives have allowed the farmers to reduce risk and also improve the quality of product and services. In addition to this, cooperatives create social relations which encourage individuals in accomplishing goals which is easier to accomplish alone. Moreover, the main reason to bring cooperatives is that farmers will reap the advantage of economies of scale in order to lower their input cost and other hiring services including transport and storage.

It is highlighted by Mojo et. al. [9] that agricultural cooperatives are called as a formal form of the collective actions of farmer for the processing and marketing of farm products and also enables farmers to have a viable production and purchasing of the farm inputs. Though, another reason to focus on the agricultural cooperatives that it is productive and effective for coping up with the issue of poor marketing. It was bringing in the Oman to increase the production and income capacity of farmers with the constant provision of the agricultural input, finance, output markets and required information [10].

\section{B. The Implications of Establishment of Cooperatives among Farmers}

It is stated by Jacobs, et. al. [11] that joining, and farming cooperative is helpful for the smallholder farmers to bring increment in their access and also bring improvement in the negotiation power to acquire a wider services ranges that incorporated extension and knowledge services, productive assets including tools and seeds. Additionally, it provides the marketing skills and thrilling information and capabilities in order to make the greater amount of sale from the products. The implications of the agricultural cooperatives also enhanced level of empowerment with the participation of facilitating smallholders during the process of decision making. The implication is also useful to negotiate effectively to have a better value chain engagement and also provide support to secure the right use of landing. However, the challenge remains is based on scaling up the project successfully. It might be compulsory for the farmers to develop management structure and alternative institutions and learn from the experiences.

It is denoted by $\mathrm{Yu} \&$ Nilsson [12] that the implication of cooperatives might face issues if external actors are focused apart from the strategy of public investment. In addition to this, a top to down approach may limit the social capital formation the also reduce the several threatening sustainability and potential benefits. Therefore, the implication and process of cooperatives needs to be done in a comprehend manner so it might not hit the working efficiency or level of high productivity.

As represented by $\mathrm{Li}$ et. al. [13], the cooperatives of farmers and its unique and compiling implications helps in the better future of the agriculture and its high growth and development. However, the common problem to the cooperative's implication is corruption which directly threatens the sustainability factors. Therefore, it is highly significant to focus on this corruption issue because it entails the negative impact on the cooperative's implementation. It is further stated that embracing transparency will be beneficial for cooperatives in order to maintain trust within the premises of their communities and it is also help in the avoidance of corruption. 
It is initiated by Heerink et al. [14] that cooperatives entail a universal appeal being instrument for the development of economic, cultural, and social concern, no matter if the record is found less than exemplary prospect. The article portrays the effectiveness of dilemmas in the development of cooperatives. Therefore, with the successful examination of the evidence to the cooperatives of agricultural credit it has raised the argument that absence of the several external prerequisites, internal consideration, and other sort of the institutional planning sounds more effective as compared to the credit cooperatives.

C. The Position of the Omani Farmers from Those Cooperatives and the State Role in Strengthening Them

According to Zhong et. al [15], Oman agricultural sector plays a significant and pivotal role is the major developmental and socio-economic prospect to have sustainable results in the rural communities. The various governmental authorities are intended to support and develop the agricultural sector in order to have the long-term contribution and sustainable results towards the national gross domestic product. In addition, the sultanate of Oman is continuously encouraging the cooperatives farmers and its vibrant role to bring the high growth and development in agricultural sector. Thus, it means that the state of role is very prominent in strengthen the cooperative farmers. They are focusing this to have a sustainable development in the agricultural sectors.

It is stated by Shumeta \& D'Haese [16] that sustainability in the agricultural sector in Oman tends to guarantee the high contribution towards the food security, poverty alienation, contribution toward the employment and most considerably improvements in the rural communities of the living standards. However, it is the main part of the strategic planning of the country because it provides an ultimate way to achieve success in the most comprehend and dynamic way by raising the standards of the agricultural sector.

It is indicted by Grashuis \& $\mathrm{Su}$ [17] that the cooperatives farmers playing a pivotal role for being a supportive contributor toward the security of food, agricultural sector sustainability and most profoundly a prospective development in rural areas in the sultanate of Oman. In addition to this, the government is continuously working to strengthen the activities of cooperatives farmers because they are providing the ultimate benefits to the agricultural sector in terms of having high food security and efficient production. This is also a good thing in terms of having the safe and sound economic development and its consequences are highly advantageous for raising GDP.

It is stated by Yang et. al. [18] that farmers are pressurized or troubled with the high homestead's sources of info costs, lacking preparations of framework, wastefulness of cultivating methods, substantial requirements to have credit offices, and poor market. This is an in all respects appalling outcome which further intensified with the administration experts' goal to evacuate every one of the endowments on the ranch input assets including agro-synthetic substances and compound manure and furthermore because of the substantial downturn in the financial conditions. In any case, cooperative farming choice has been come into the presence as a lively path so as to effectively activate designers to shape the pool and gathering assets. This causes farmers to turn out to be increasingly viable in the creation of agrarian exercises. It is also stated that cooperative farming enables farmers to have a sound generation. The reason cooperatives are utilized as a suitable device so as to upgrade the rancher's exhibition in agrarian part [19].

\section{METHODOLOGY}

The study seeks to complete and prepare the study relied on a variety of sources through which the information can be obtained accurately and clearly to contribute to solution of the problem of the study and provide excellent results serve to study and contribute to reach some goals of the study and achieve them from a different perspective. The study used two sources for the completion of this study, and they are written primary sources such as: electronic articles, magazines and newspapers and secondary sources such as: questionnaire and interviews.

\section{A. The Argument for the Research Method}

The study used the philosophy of realism to deliver real and accurate information about cooperative in Oman. The philosophic of realism is the view that says the entities exist independently of understanding, or independently of people theories [20]. Also, it is the opinion that all features of the universe refer to realism [21]. This philosophy is the best to follow because it will clarify what existence level of farmer cooperatives in the country is and what is the farmer's opinion. It will bring up a reasonable idea that can be followed by the farmers to implement cooperatives.

The study used the deductive approach due to the lack of theory and generating new ideas based on farmer cooperatives in the Sultanate of Oman. Collecting all the data relate to the cooperatives and using the information and data from questionnaire and interview.

Moreover, the use of mixed method, which is qualitative and quantitative methods in this study. Furthermore, the conclusion of quantitative analysis is based on evidence, logic and arguments [22]. However, in the qualitative method the researcher studies the field of cooperatives, make interview and ask questions about the study topic. In addition, collecting data from many websites and making questionnaire. The researcher can be an instrument of data collection [23]. The study used interviews, float questionnaires, different websites and academic article to collect reliable data to complete this study.

\section{B. State Ethical Codes}

No research can draw a professional research and added value without following ethical codes. Any researcher or writer should follow the ethical codes to have efficient research. The study used trusted references to collect all information needed for this study. In fact, this study was based on collecting information, data and evidence through distributing the questionnaire and conducting interviews with the appropriate sample. On the other hand, the preparation of the questionnaire requires a set of questions that are suitable for all age groups and nationalities, an overview of the project and an explanation of some questions. However, the study focused on conducting interviews with people who have a wide background on farmers' cooperatives in Oman and the 
researcher did not force the interviewer in any question. In addition, copying and pasting were avoided so there is no plagiarism included in this research.

\section{Sampling}

The study depends on the accuracy of the selection of the appropriate sample that can enhance the value of the study by providing valuable information and high quality, so the study can rely on them to prove his hypotheses and achieve the success of the study. On the other hand, the wrong selection of the sample may lead to a hurdle in achieving goals and delivering better results. Therefore, the process of selecting the appropriate sample was based on special techniques that contribute to the collection of information and data.

The study is based on developing plans to implement strategies, record observations, and identify the type of problem. Also, to organizing the objectives of the study and provide a detailed explanation of the most relevant results obtained in the distribution of the questionnaire and conduct interviews and analyses findings effectively. In fact, the volume of information obtained from some books, articles and newspapers cannot be denied.

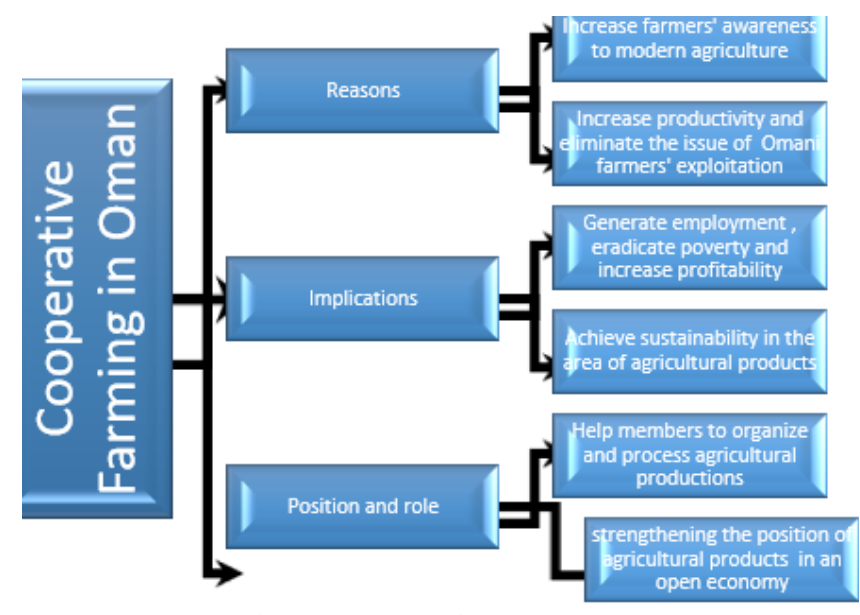

Fig. 1. Conceptual framework.

\section{Reasons of the Establishment of Cooperatives among Farmers in Oman}

The Sultanate of Oman is characterized by its geographical location and climate, which contributes to the growth of different types of agricultural products. The Sultanate has recently noticed a slight decline in the productive efficiency of crops and agricultural soil degradation due to lack of awareness among some farmers of the quality of tools, equipment and fertilizer useful for agricultural land. The Sultanate has planned to establish and supervise several farmers 'cooperatives, provide support and guidance to farmers and encourage them to become members of farmers' cooperatives. The main objective of cooperatives is to increase profits (raising the state's economy), eradicate poverty, hunger and unemployment, exploit rural land in the right way and solve problems facing farmers in marketing or agriculture.

Omani farmers demonstrated the importance of farmers' cooperative in Oman through its role in preserving the rights of farmers, encourage them to invest and marketing their products and provide advice on everything related to agricultural products and how to grow and care them.
Based on the result of the interview by the researcher, Omanis seek to exploit their agricultural land and rehabilitate it to be suitable for farming, which contributes to the production of agricultural crops in large quantities and improve the livelihoods of Omani farmers and raise the state economy. The concept of agricultural cooperatives has been appeared in the last few days. The Sultanate has put strategic plans that encourage farmers to apply these cooperatives among farmers to eliminate the problems faced by some farmers and to provide the main requirements of equipment, tools and fertilizers, which in turn increase productivity of farmers. On the other hand, the lack of profit and lack of exploitation of agricultural areas properly. In addition, the lack of food has contributed to the spread of poverty, disease, and the death of many people in other countries neighboring Oman that led to the establishment of farmers' cooperatives in Oman.

\section{E. The Implications of the Establishment of Cooperatives among Farmers}

The traditional concept of farmers' cooperatives has been popular among many farmers, relying on traditional equipment. However, for almost 70 years, the modern concept of farmer cooperatives has emerged that has contributed to the elimination of hunger through the achievement of food security and balance in the world, especially Oman. Also, it has contributed to the elimination of unemployment by creating new jobs and providing a safe environment for work. Besides, it has contributed to the eradication of poverty through increased productivity and improved livelihoods. Many farmers relied on cooperatives to get money instead of borrowing from banks [24]. Consequently, they could buy the necessary equipment, tools, and fertilizers for agriculture, which would save time, effort and money and would be able to market their products and compete in the market.

Based on the result gathered and analyzed by the researcher, farmers' cooperative in Oman contribute to raising the Omani economy and achieve its sustainable development, in fact Oman has historically been one of the most important commercial centers. It has a commercial relationship with many countries because of its unique location on the Indian Ocean. Oman had sought to export its agricultural products to many countries such as India and East Africa.

The respondents' viewed generally that cooperatives among farmers are designed to meet the needs of its members and seek profit and sustainability. They added that cooperatives among the Omani farmers contribute to increasing food security and reducing hunger, poverty and unemployment and it means that some farmers are keen to implement and apply farmers' cooperatives policy to achieve food security and eliminate unemployment.

Finally, the researcher implied that the existence of cooperatives among farmers within the Sultanate of Oman will increase Omani farmers' production output in terms of agricultural products and to sustain food security within the Sultanate of Oman and beyond. Farmers' cooperatives can further eliminate poverty, unemployment and livelihood improvements. 
One reliable respondent pointed that cooperatives have contributed farmers to achieving security and food balance in the Sultanate and put many plans and strategies to eliminate unemployment, hunger and poverty and to provide a suitable environment for collective action. In addition, increase the percentage of profit and achieve sustainable development.

\section{F. The Position of the Omani Farmers from Those} Cooperatives and the Role of the State in Strengthening Them

Farmers 'attitude towards the concept of farmers' cooperatives is very important. It depends on the level of awareness and knowledge of farmers about the importance of cooperatives and their focus on their positive results that contribute to achieving their goals and meet their needs. They will have the desire to join farmers' cooperatives and contribute to decision making and the putting of some useful proposals related with farmers' cooperatives. On the other hand, if the farmer does not have a background and awareness of the importance of the cooperatives and the purpose of its establishment, the farmer always thinks the cooperatives consequences and negative effects that may lead to the loss of real estate and his property. Consequently, the farmers are not encouraged to join these cooperatives and he believes that he will achieve greater losses. Therefore, farmers may decide to take a loan from the bank to buy agricultural inputs. The Sultanate of Oman seeks to contribute to the enhancement of cooperatives among farmers through the establishment of several conferences and training workshops to present the most essential relevant results of cooperatives among farmers, such as increasing employment opportunities, increasing food production, improving livelihoods, contributing to saving time, effort and money and reducing poverty in rural areas. On the other hand, the idea of establishing farmer cooperatives may be a new innovative idea to meet the needs of farmers, profit and sustainable development and support for the provision of money to purchase equipment, tools and fertilizers used in agriculture [27]. Otherwise, the idea of farmers' cooperatives may need time to convince other farmers of the importance of cooperatives and their positive results that benefit the community and the individual.

Based on the results gathered from this study, the strong emphasis of organizing the farmers' cooperative in Oman is to help the Omani farmers to sustain the agriculture sector to be able to improve their livelihood through the provisions of job opportunities among the people of Oman and reducing the size of unemployment. Furthermore, cooperatives contribute farmers to finding solutions to many problems such as land exposure to salinity, loss of soil fertility and lack of equipment used in irrigation, land tillage and the transfer of crops to the market.

Further result from the data gathered in this study, analyzed that cooperatives among farmers are unknown and some farmers ignore the importance of cooperatives while others avoid entry into farmer cooperatives, because some farmers are afraid of getting into problems with other farmers and some farmers are unable to adapt to cooperatives. Data obtained from the questionnaire have shown that some Omani farmers believed that cooperatives seek to reject farmers' decisions and seek to enforce their laws rather to follow these laws and abide by them.

Finally, farmers' position on the concept of farmers' cooperatives depends on the level of awareness and prior knowledge of these farmers on the importance of these cooperatives and the reasons for their establishment and the effects of the application of farmers' cooperatives. If a farmer has a background on farmers' cooperatives, you will find him accelerated to be one of its members to improve his physical status and increase the proportion of profits and achieve his personal goals. If a farmer does not have a background or idea about those cooperatives, you will find him reject this idea and consider it a loss of other rights. On the other hand, Oman seeks to develop its agricultural sector and raise awareness and knowledge among farmers about the importance of agricultural cooperatives through the establishment of many conferences, seminars and training workshops that contribute to the rehabilitation of farms to accept the idea of cooperatives and its importance.

\section{RESULTS}

TABLE I: FINDING AND ANALYSIS

\begin{tabular}{|c|c|c|c|}
\hline \multirow{2}{*}{$\begin{array}{l}\text { No. of } \\
\text { Question }\end{array}$} & \multirow[t]{2}{*}{ Questions } & \multicolumn{2}{|c|}{$\begin{array}{l}\text { Results out of } 100 \% \\
\text { respondents }\end{array}$} \\
\hline & & Yes $(\%)$ & No (\%) \\
\hline 1. & $\begin{array}{l}\text { Do Omani farmers are clear with } \\
\text { the objective of farmers' } \\
\text { cooperative in Oman? }\end{array}$ & $80 \%$ & $20 \%$ \\
\hline 2. & $\begin{array}{l}\text { Do you encourage the } \\
\text { establishments of farmers' } \\
\text { cooperative in the Sultanate of } \\
\text { Oman? }\end{array}$ & $58 \%$ & $42 \%$ \\
\hline 3. & $\begin{array}{l}\text { Do you think that farmers' } \\
\text { cooperative can contribute the } \\
\text { economic development and } \\
\text { sustainability in the global level? }\end{array}$ & $49 \%$ & $51 \%$ \\
\hline 4. & $\begin{array}{l}\text { Farmers' cooperative in Oman } \\
\text { contributes food sustainability, } \\
\text { reducing hunger, poverty, and } \\
\text { unemployment. }\end{array}$ & $62 \%$ & $48 \%$ \\
\hline 5. & $\begin{array}{l}\text { Do farmers' cooperatives in Oman } \\
\text { considered as a social project? }\end{array}$ & $31 \%$ & $69 \%$ \\
\hline 6. & $\begin{array}{l}\text { Farmers' cooperative reduces the } \\
\text { rate of losses of those who failed to } \\
\text { join. }\end{array}$ & $25 \%$ & $75 \%$ \\
\hline
\end{tabular}

The successful study relies on a series of strategic plans and interrelated goals to collect different sources, identify the problem of study, develop appropriate solutions, develop a set of hypotheses and seek to prove them and achieve from the results obtained. On the other hand, in order to collect as much information as possible, the questionnaire has been distributed and interviews conducted on the appropriate sample to achieve better results that contribute to the service and promotion of the study.

\section{CONCLUSION AND RECOMMENDATIONS}

First, according to the survey and interview the cooperative of farmers is not clear in the Sultanate, therefore there is lack of awareness among farmers and people about theses cooperatives. Therefore, Farmers' Cooperatives Organization may face rejection by some farmers and delay in the application of farmers' cooperatives.

Second, misunderstanding of the advantages and 
disadvantages of cooperatives. Some people's opinion are cooperatives may lead to lose their rights and lands. However, Farmer's cooperatives are one of the most important economic and social projects in the world. It seeks to reduce poverty, eradicate hunger, create jobs for millions of people and increase food production efficiency. In addition, it seeks exploitation and processing of agricultural areas in an appropriate way, which contributes to improving livelihoods and creating a spirit of cooperation and solidarity among farmers.

Third, many responses showed cooperatives are for social project only, furthermore, the Farmers' Cooperatives Organization seeks to eliminate the difficulties that farmers may face such as buying tools and equipment that contribute to saving time, effect, money, and reserving farmers' rights.

Fourth, the concept of farmer's cooperatives is not known in rural areas, which make them not accepting these cooperatives. Therefore, the Sultanate is seeking to spread awareness of the importance of applying cooperatives among farmers and their role in achieving security and job satisfaction for farmers in difficult changing circumstances.

The study relied on the putting of many strategies that contribute to achieving the goals and identifying and overcoming problems such as the strategy of planning and researching the facts and appropriate evidence that enhance the value of the study. Also, the data analysis strategy to verify the results of the study. Therefore, the researcher puts some of the recommendations related to this study, which may be used in the future as a reference for many studies and researches, which illustrate the importance, effects and reasons for the establishment of farmers' cooperatives, as follows:

1. In order to minimise farmers' inefficiencies and ineffectiveness by the Omani farmers, the researcher suggests that Omani farmers should be able to participate in private and public sectors' agricultural research and information services in order to increase their awareness and to be able to contribute to the growth of Oman's agricultural output. There are many farmers in rural areas do not know the meaning of this cooperative and the benefit that they can get from these cooperatives. Therefore, they refuse to join cooperatives and believe that such cooperatives may lead to losing their rights and jobs.

2. The Omani farmers should create stronger relations with themselves in order to establish or organise their own "Farmers' Cooperative society" to be able to benefit them from economies of scale by lowering their operating costs especially on logistics and transport.

3. The Royal government of Oman should firmly provide technology transfer extension to Omani farmers' cooperatives society throughout the Sultanate, helping them their needs to facilitate proper technological (know-how) development.

4. Omani farmers should strengthen their integration of economic activities such as moving their capital in order to provide credit and inputs to be able to increase their agricultural production to themselves.

\section{ACKNOWLEDGMENT}

In all humbleness and gratefulness to acknowledge our depth to all those who have helped us to complete this research. Secondly, we would like to thank our IMCO family who supported and helped us gathering information despite of being busy they still find a way to help us in making this paper unique and successful. Most special thanks to our LTM colleagues for their contributions that are highly appreciated and acknowledged.

\section{REFERENCES}

[1] Chiputwa, B., Spielman, D. J., \& Qaim, M. (2015). Food standards, certification, and poverty among coffee farmers in Uganda. World $\begin{array}{ll}\text { Development. } & \text { [online].66, 400-412.Available at }\end{array}$ http://www.waeaonline.org/UserFiles/file/JAREMay20169Ihli324345online.pdf[Accessed 26 June 2019].

[2] Feng, L., Friis, A., \& Nilsson, J. (2016). Social capital among members in grain marketing cooperatives of different sizes. Agribusiness. [online]. 32(1), 113-126. Available at: https://www.researchgate.net/publication/275718256_Social_Capital_ among_Members_in_Grain_Marketing_Cooperatives_of_Different_S izes [Accessed 30 June 2019].

[3] Hakelius, K., \& Hansson, H. (2016). Measuring changes in farmers attitudes to agricultural cooperatives: evidence from Swedish agriculture 1993-2013. Agribusiness. [online]. 32(4), 531-546. Available at: https://onlinelibrary.wiley.com/doi/pdf/10.1002/agr.21464 [Accessed 01 July 2019].

[4] Chiputwa, B., \& Qaim, M. (2016). Sustainability standards, gender, and nutrition among smallholder farmers in Uganda. The Journal of Development Studies. [online].52(9), 1241-1257. Available at: https://www.econstor.eu/bitstream/10419/104816/1/812454057.pdf.

[5] Hao, J., Bijman, J., Gardebroek, C., Heerink, N., Heijman, W., \& Huo, X. (2018). Cooperative membership and farmers' choice of marketing channels-Evidence from apple farmers in Shaanxi and Shandong Provinces, China. Food Policy. [online].74, 53-64. Available at: https://research.wur.nl/en/publications/cooperative-membership-andfarmers-choice-of-marketing-channels-e[Accessed 01 July 2019].

[6] Liang, Q., Hendrikse, G., Huang, Z., \& Xu, X. (2015). Governance structure of Chinese farmer cooperatives: evidence from Zhejiang province. Agribusiness. [online]. 31(2), 198-214.Available at: https://onlinelibrary.wiley.com/doi/abs/10.1002/agr.21400 [Accessed 27 June 2019]

[7] Stamm, M. C. (2018). Ruerd Ruben, Paul Hoebink (eds.): Coffee certification in East Africa: impact on farmers, families and cooperatives. Agriculture and Human Values. [online]. 35(2), 539-540. Available

https://ideas.repec.org/a/spr/agrhuv/v35y2018i2d10.1007_s10460017-9807-7.html [Accessed 29 June 2019].

[8] Van Rijsbergen, B., Elbers, W., Ruben, R., \& Njuguna, S. N. (2016). The ambivalent impact of coffee certification on farmers' welfare: a matched panel approach for cooperatives in Central Kenya. World Development. [online].77, 277-292.Available at: https://ideas.repec.org/a/eee/wdevel/v77y2016icp277-292.html [Accessed 28 June 2019].

[9] Mojo, D., Fischer, C., \& Degefa, T. (2017). The determinants and economic impacts of membership in coffee farmer cooperatives: recent evidence from rural Ethiopia. Journal of Rural Studies. [online]. 50, 84-94. Available at: https://www.researchgate.net/publication/312218826_The_determina nts_and_economic_impacts_of_membership_in_coffee_farmer_coope ratives_recent_evidence_from_rural_Ethiopia [Accessed 01 July 2019].

[10] Van Dijk, W. F., Lokhorst, A. M., Berendse, F., \& de Snoo, G. R. (2015). Collective agri-environment schemes: How can regional environmental cooperatives enhance farmers' intentions for agrienvironment schemes? Land Use Policy. [online]. 42, 759-766. Available

at: https://www.researchgate.net/publication/236888395_Temporal_effec ts_of_agri-environment_schemes_on_ditch_bank_plant_species [Accessed 30 June 2019].

[11] Jacobs, K., McKee, G., \& Park, J. (2018). Case Studies of Cooperatives in the Value Chain: Texas Cooperatives. [online]. (No. 2166-20187872). Available at: https://ideas.repec.org/p/ags/ncer18/280131.html [Accessed 30 June 2019]. 
[12] Yu, L., \& Nilsson, J. (2018). Social capital and the financing performance of farmer cooperatives in Fujian Province, China. Agribusiness. [online]. 34(4), 847-864.Available at: https://onlinelibrary.wiley.com/doi/abs/10.1002/agr.21560 [Accessed 29 June 2019].

[13] Li, F., Liu, Y., \& Wu, F. (2019, February). Analysis of the Present Situation of and Countermeasures for Farmers' Specialized Cooperative in China-Laos Boarder Area. In 2018 International Workshop on Education Reform and Social Sciences (ERSS 2018). Atlantis Press. .[online]. Available at: https://www.atlantispress.com/proceedings/ncce-18/sessions/2037 [Accessed 02 July 2019].

[14] Heerink, N., Heijman, W., \& Huo, X. (2018). Cooperative membership and farmers' choice of marketing channels-Evidence from apple farmers in Shaanxi and Shandong Provinces, China. Food Policy. [online]. 74, 53-64. Available at: https://ideas.repec.org/a/eee/jfpoli/v74y2018icp53-64.html [Accessed 28 June 2019].

[15] Zhong, Zhang, \& Bijman, J. (2018). Vertical coordination and cooperative member benefits: Case studies of four dairy farmers' cooperatives in China. Journal of cleaner production. [online]. 172, 2266-2277. [online]. Available at: http://library.wur.nl/WebQuery/wurpubs/530601 [Accessed 26 June 2019].

[16] Shumeta, Z., \& D'Haese, M. (2018). Do Coffee Farmers Benefit in Food Security from Participating in Coffee Cooperatives? Evidence from Southwest Ethiopia Coffee Cooperatives. Food and nutrition bulletin. [online].39(2), 266-280. [online]. Available at: https://journals.sagepub.com/doi/10.1177/0379572118765341 [Accessed 01 July 2019].

[17] Grashuis, J., \& Su, Y. (2019). A review of the empirical literature on farmer cooperatives: Performance, ownership and governance, finance, and member attitude. Annals of Public and Cooperative Economics. [online]. 90(1), 77-102. Available at: https://onlinelibrary.wiley.com/doi/full/10.1111/apce.12205 [Accessed 03 July 2019].

[18] Yang, H., Vernooy, R., \& Leeuwis, C. (2018). Farmer cooperatives and the changing agri-food system in China. China Information. [online] 32(3), 423-442. Available at: https://journals.sagepub.com/doi/abs/10.1177/0920203X16684504 [Accessed 26 June 2019].

[19] Ma, M., \& Zhu, H. (2018). Efficiency of Decisions under Membership Heterogeneity and Government Regulations: Insights from Farmer Cooperatives in China. [online]. Available at: https://www.journals.uchicago.edu/doi/abs/10.1086/701318?mobileUi $=0 \&$ [Accessed 30 June 2019].

[20] Phillips, D. (1987). Philosophy, Science and Social Inquiries. [Online] 20 p 205. Available at https://www.ualberta.ca/international-institutefor-qualitative-methodology/media-library/international-institute-ofqualitative-methods/webinars/master-class/2017/jmaxwellrealismand-qualitative-research.pdf.

[21] Schwandt, T. (1997). Definitions: Positivism. [Online] 21, pp.103. Available at https://uk.sagepub.com/sites/default/files/upmbinaries/40425_Chapter1.pdf.

[22] Trochim, (2006). Inductive and Deductive Research Aproaches. [online]. 22, p.3. Available at https://files.eric.ed.gov/fulltext/ED542066.pdf.

[23] Soiferman, L. (2019). Inductive and Deductive Research Approaches Compare and Contrast Inductive and Deductive research Approaches, [online] 23, pp.5,6,7. Available at: https://files.eric.ed.gov/fulltext/ED542066.pdf [Accessed 9 May 2019].

[24] Hussain, H. (2017). Cabinet: exempt farmers and cooperative societies from the benefits of loans [Online].Alrai.[viewed 10 May 2019].Available from: http://alrai.com/article/10390127/.

[26] Ma, W. and Abdulai, A. (2017). The economic impacts of agricultural cooperatives on smallholder farmers in rural China, [online] pp.1,2,5. Available https://www.researchgate.net/publication/319862895_The_economic_ impacts_of_agricultural_cooperatives_on_smallholder_farmers_in_ru ral_China [Accessed 20 May 2019].

[27] Al-Salouli, W. (2018). «Agricultural Fund»: We target new technology projects with $70 \%$ of funding [Online]. Aleqt. [viewed 05 May 2019]. Available from: http://www.aleqt.com/2018/11/27/article_1496676.html.

[28] Al-Anbari, J. S. K. (no date). Understanding constraints to the development of the agricultural sector in Oman: An application of the Theory of Planned Behaviour Juma Said Khalfan Al-Anbari [online]. pp.v,vi,vv. [Viewd 03 Feb 2019].Available from:
http://centaur.reading.ac.uk/71952/1/19028222_Al-

Anabari_thesis.pdf.

[29] Bateman, M. (2007). Financial cooperatives for sustainable local economic and social development. Small Enterprise Development, [online] 18(1), pp.37-49. Available at: https://www.researchgate.net/publication/233703812_Financial_coop eratives_for_sustainable_local_economic_and_social_development [Accessed 13 May 2019].

[30] Bello, D. (2005). The Role of Cooperative Societies in Economic Development, [online] 20, pp.14-16. Available at: https://mpra.ub.unimuenchen.de/23161/1/The Role of Cooperatives in Economic_Dev elopment.pdf [Accessed 14 May 2019].

[31] Benson, D., Carabini, C., Brander, D. and Romenteau, A. (2017). Good practices in international cooperative development. Why creating a knowledge sharing culture is key for international cooperative development work, [online] 61, p. 39. Available at: https://coopseurope.coop/sites/default/files/REPORT_CEDP_Good\% 20pracrices\%20in\%20int1\%20development.pdf [Accessed 2 Jun 2019].

[32] Business Studies. (n.d.). Co-operative Society, [online] 102, pp.94,95,96. Available at: http://old.nios.ac.in/Secbuscour/cc09.pdf [Accessed 4 Feb. 2019].

[33] C. Tortia, E., Valentinov, V. and Iliopoulos, C. (2013). Agricultural Cooperatives, [online] 2(1), pp.24,25,26,27. Available at: https://www.researchgate.net/publication/255697522_Agricultural_C ooperatives [Accessed 6 Feb. 2019].

[34] Hun, S., Ito, S., Amekawa, Y. and Isoda, H. (2018). Impacts of Agricultural Cooperatives on Farmers' Revenues in Cambodia: A Case Study of Tram Kak District, Takeo Province, [online] 10(2), p.85. Available https://www.researchgate.net/publication/322442727_Impacts_of_Ag ricultural_Cooperatives_on_Farmers'_Revenues_in_Cambodia_A_Ca se_Study_of_Tram_Kak_District_Takeo_Province [Accessed 20 May 2019].

[35] International Labour Conference. (2001). Promotion of cooperatives, [online] 145, pp.142, 141, Available at: https://www.ilo.org/public/english/standards/relm/ilc/ilc89/pdf/rep-v2.pdf [Accessed 6 Mar. 2019].

[36] MAF and ICBA.Oman Salinity Strategy. (2012). GOVERNANCE LEGAL/REGULATORY FRAMEWORKS AND POLICIES IN AGRICULTURE AND WATER, [online] 30, pp.14,15,26. Available at https://www.google.com/url?sa=t\&rct=j\&q=\&esrc=s\&source=web\&c $\mathrm{d}=1 \&$ ved=2ahUKEwjYlfDUpoDjAhVkSxUIHXh1DTIQFjAAegQIA RAC\&url=http\%3A\%2F\%2Fmaf.gov.om\%2FDownload.ashx\%3FFil e\%3DFCKupload\%2FFile\%2Fbooks\%2Fannex4.pdf\&usg=AOvVaw 2REEWXJwnXr6431GoWQNU4 [Accessed 1 Mar. 2019].

[37] Maxwell.J.(no date). Realism and Qualitative Research [online]. pp.1,2. [viewed 04 April 2019]. Available from https://cloudfront.ualberta.ca/-/media/ualberta/faculties-andprograms/centres-institutes/international-institute-of-qualitativemethods/webinars/master-class/2017/jmaxwellrealism-andqualitative-research.pdf.

[38] McInerney, E. (2012). Cooperatives. Enhancing cooperatives' impact in the food and agriculture sector: key to implementing the Sustainable Development Goals, [online] pp.2,3,4,5,6. Available at: https://www.un.org/esa/socdev/egms/docs/2016/Coops2030Agenda/McInerney.pdf [Accessed 1 Jun. 2019].

[39] Ministry of agriculture, (2011). Agriculture and Livestock Five-Year Research Strategy 2011-2015, [online] 52, pp.48, 37. Available at: https://www.google.com/url?sa $=t \& r c t=j \& q=\&$ esrc $=s \&$ source $=w e b \& c$ $\mathrm{d}=1 \&$ ved=2ahUKEwjKq9jLooDjAhW1RRUIHcErAxUQFjAAegQI AxAC\&url=http\%3A\%2F\%2Fwww.maf.gov.om\%2FDownload.ashx \%3FFile\%3DApp_Uploads\%2FBulletins\%2FFiles\%2Fmoa\%2520co v\%25202\%2520fin.pdf\&usg=AOvVaw3Qsfw8nrB5ms8ge0ZbYaNv [Accessed 1 Apr. 2019].

[40] Ortmann, G. and King, R. (2009). Agricultural Cooperatives I: History, Theory and Problems, [online] 30, pp.43,44,45,46,47,48. Available at: https://tind-customer-agecon.s3.amazonaws.com/e947a433-d9bb4ef3-bbcf-2bd819ac7fb1?response-contentdisposition=inline $\% 3 \mathrm{~B} \% 20$ filename $\% 2 \mathrm{~A} \% 3 \mathrm{DUTF}$ $8 \% 27 \% 2746010040$.pdf\&response-content-

type=application\%2Fpdf\&AWSAccessKeyId=AKIAXL7W7Q3XHX DVDQYS\&Expires $=1561322654 \&$ Signature $=\mathrm{mLn} 1 \mathrm{wpEYV40TAKV}$ yrUKn8O\%2BnZ\%2B8\%3D [Accessed 12 May 2019].

[41] Saner, R., Yiu, L. and Filadoro, M. (2012). Cooperatives. Cooperatives- Conspicuously absent in trade \& development discourse, [online] pp.2,3. Available at: https://www.wto.org/english/forums_e/ngo_e/CSEND_cooperatives_i nclusive growth.pdf [Accessed 9 Mar. 2019]. 
[42] Tesfay, A. and Tadele, H. (2013). The Role of Cooperatives in Promoting Socio-Economic Empowerment of Women. Evidence from Multipurpose Cooperative Societies in South-Eastern Zone of Tigray, Ethiopia, [online] 12, pp.1,2,3. Available at: https://www.researchgate.net/publication/275745206_The_Role_of_C ooperatives_in_Promoting_Socio-

Economic_Empowerment_of_Women_Evidence_from_Multipurpose _Cooperative_Societies_in_South-Eastern_Zone_of_Tigray_Ethiopia [Accessed 16 Apr. 2019].

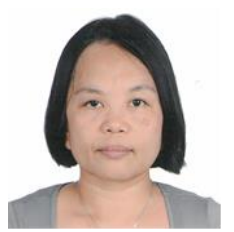

Dr. Adela Paingan Balasa is an Assistant Professo in Economics at International Maritime College Oman (IMCO) for more than 11 years. She received her Doctorate Degree in Public Administration at the university of Manila, Philippines in 2002. She is an experienced Lecturer in Economics and business in more than 25 years. Dr. Balasa published an article on "COVID - 19 on Lockdown, Social Distancing and Flattening the Curve A Review. European Journal of Business and Management Research, 5(3). https://doi.org/10.24018/ejbmr.2020.5.3.316.

Ghadeer Saif Khamis Al- Mashaikhi, Al Buraimi, Governorate, Sultanate of Oman. She is a graduate of Logistics and Transport Management batch 2019 at International Maritime College Oman, Sohar.

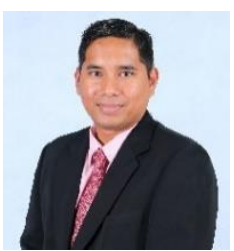

Dr. Noorul Shaiful Fitri Abdul Rahman is an Associate Professor in the Maritime Logistics Operation and Transport fields. He is now the Head of Department Logistics and Transportation Management, International Maritime College Oman (IMCO). He received his Master in Transport and Maritime Management from ITMMA, University of Antwerp, Belgium, in 2009, Ph.D in Maritime Logistics Operations from Liverpool John Moores University, UK, in 2012 and Post-Doctorate fellowship in Maritime Logistics Operations from University of Liverpool, in 2015. Up to date, he has published of about 52 refereed journals and 41 conference papers under research interests of logistics management, warehousing operations, supply chain studies, logistics 4.0, maritime operations, shipping and port management, container terminal, and risk assessment management by using various multiple criteria decision-making approaches, e.g: Bayesian Networks, Analytical Hierarchy Process, Fuzzy Logic, Rule-based Reasoning, TOPSIS, Risk Matrix, Broda Method, Bow-tie, Critical Path Analysis, Systematic Literature Review, Evidential Reasoning, Fault Tree Analysis, Event Tree Analysis, Cause and Effect Analsysi, SWOT/TOWS Analysis, etc.. 